\title{
Structural-Functional Analysis of Ukrainian Banking System
}

\section{Elena Zarutska}

Doctor of Economics, Head of Finance and Banking Department, Director of the Regional centre of innovative development of Ukraine's banking system of the University of Customs and Finance, Ukraine.

\begin{abstract}
The article analyzes the changes in the financial condition of the banking system during the last years, during the period of intensive reduction of the banking services market. The author has established a stable distribution of the banking services market for homogeneous groups throughout the research period, the features of business models and the risk profiles of banks of each group have been identified. An assessment of the financial stability of each bank is proposed to be carried out based on an analysis of the bank's trajectory on the Kohonen self-organizing map constructed during the research period.

Structural-functional analysis of the banking system is intended for the analysis of gradual structural changes in comparison with the previous reporting periods, the identification of specific characteristics of each group of banks, the relationship between groups and the place of each bank. This analysis allowed to identify the main problematic aspects of banks' activities, which affected the deterioration of financial stability of the system and individual banks.
\end{abstract}

Keywords: structural-functional analysis, financial system indicators services, stability of banking system, self-organizing map.

\section{JEL Classification: G21.}

(C) The Author, 2018. This article is published with open access at Sumy State University.

\section{Introduction}

The banking system of Ukraine consists of many banks, even after a significant reduction in recent years. As of October 1, 2017, 91 banks with total assets of 1299 billion UAH worked in the country, for six years the system has been halved and the withdrawal of banks from the market continues. Investigations of the banking system transformations that have taken place in recent years should be conducted with the help of structural and functional analysis of the distribution of banking services market between homogeneous groups of banks with similar structural characteristics of assets and liabilities, income and expenses, a list of priority operations and features of the client base. An important advantage of the method is the ability to consider a significant number of indicators for the formation of homogeneous groups of banks.

Published quarterly accounts of banks provide an opportunity to calculate the share of the main components of assets, liabilities, income and expenses for each bank, and to combine the values of the 23 structural indicators proposed by the author in a large database. The groups are displayed on the self-organized map of Kohonen as separate geographical objects. The close position of the groups on the map indicates the presence of common features and vice versa, the groups with the greatest distance, and have significant differences in many signs. Thus, the formation of groups affects only the value of all structural indicators, which is considered simultaneously.

In the process of studying the structure of the banking system of Ukraine, we formulated the idea of expediency and the possibility of isolating homogeneous groups of banks that are close:

$>$ according to the structure of the main aggregates of assets, liabilities, income and expenses;

$>$ priority in the provision of services;

$>$ on the level and structure of the main types of bank risks;

$>$ response to external shocks.

The study of changes in the size and characteristics of groups allows us to assess the state of the general banking system, the situation of individual groups and individual trajectories of banks. Banks with a balanced balance structure, ie, a controlled level of major types of risks, are financially sustainable. Other groups are characterized by specific characteristics. For example, a group of retail lending banks has an increased level of commission income in the structure of profits, a large amount of reserves for credit risks compared with the average value we can only consider banks with a balanced structure of assets and liabilities, which for a long 
time do not change the position in the center of the map. The geographic neighborhood of the regions on the self-organized map of Kohonen is evidence of close characteristics, the diagonal distance is about significant differences. Even if the functional specialization accompanied by the corresponding structural imbalance provides certain temporary advantages to the bank, its consequence is necessarily to increase the vulnerability of the bank to the influence of negative external factors, the inability to dynamically adapt to the transformational changes in the market. This conclusion was confirmed by a significant number of banks that lost their financial stability during financial and economic crises.

Of relevance, the structural-functional analysis acquires during the period of significant changes, when the trajectories of many banks occur in groups with critical features, and the groups themselves move to the selforganized map Kohonen. Most groups during the research period occupy the same position on the Kohonen self-organized map. Interpreting the location of a group on a map and influencing the topology of individual indicators is an important feature of the system. Separate indicators combine groups around themselves, others do not have a single extremumin the system. A group of banks dependent on interbank resources is characterized by increased currency risks due to a significant share of liabilities in foreign currency. In our view, financially stable in the strategic perspective, an interpretation of their influence on the formation of a map topology needs an analysis of other indicators. There are cases when groups are formed not continuously but only at certain periods, which can also indicate some qualitative changes in the structure of the system.

With the help of a standardized procedure for constructing structurally-functional groups of banks that take the form of separate regions of the Kohonen self-organizing map, stable relationships of banks within groups with inherent characteristics are revealed. The toolkit of the self-organized map Kohonen provides simultaneous consideration of structural characteristics of banks and the visual representation of large data sets consisting of many parameters.

\section{Literature review}

The structural and functional analysis of banks' financial sustainability is based on classical approaches to assessing the financial status of banks, the reasons for their loss of solvency and the lack of adequate risk management (ECB, 2017). The strategy of banking regulation and risk-based supervision is implemented in the current approaches of the National Bank of Ukraine (NBU, 2018). The analysis of business models of banks provides for the application of various methods of economic and mathematical modeling of bank risks. The Self-Organizing Maps toolkit offers wide-ranging opportunities for the correct processing of large amounts of data (Kohonen, T, 2001), which also provides statistical reporting by banks. The use of the toolkit of the self-organized map Kohonen actively spreads in modern scientific works. According to the data of enterprises using neural networks, one can choose the best development model and predict their bankruptcy (Severin E., 2010), (Jarvinen, J., Linnakangas, J, 2012), (Lin, WY, Hu, YH and Tsai, CF, 2012). Also, Sarlin, $\mathrm{P}$ and Peltonen, T (2013) proposed SOFSM financial stability technology to study systemic risks. The use of the Kohonen self-organized map to predict financial failures is one of the promising areas of modern research (du Jardin, P and Severin, E, 2012). Rutherford, MW (2016) proposed a financial indicator in the Survey of Small Business Finances. AghaeiRad, A., Chen, N. and Ribeiro, B. (2017) used a self-organized Kohonen map to analyze credit risk. The procedure for forecasting stock prices using the self-organized cohogen card is proposed by Hsu, CM (2012). Tkac, M. and Verner, R. (2015) proposed a systematic review of the use of neural networks in business.

Various studies show that self-organizing map types of banks proved to be particularly vulnerable. Mergaerts, F and Vennet R. (2015) reviewed the impact of banking business models on performance and risk indicators, with more than 500 banks from 30 European countries, from 1998 to 2013. Their findings show that retailoriented banks perform better both in terms of both profitability and stability and that diversification improves profitability, but also increases susceptibility to distress. Their identification strategy is based on factor analysis. Beltratti, A. and Stulz, R.M., (2012) supportives of theories that emphasize the fragility of banks financed by short-term capital market financing. They proved that banks with more shareholder-friendly boards were significantly worse during the crisis than other banks, were not less risky before the crisis and reduced loans more during the crisis. Altunbas et al. (2011, report that low capital, large balance sheets, reliance on short-term market financing and aggressive credit growth can cause distress while a strong deposit ratio and higher income diversification will improve resilience.

Unlike most studies in the field of analyzing business models of banks, we solve the problem of isolating homogeneous groups of banks without prior subjective assumptions. For the formation of groups, the selforganized Kohonen card and large amounts of reporting data on the structure of assets, liabilities, income and 
expenses are used. The use of this approach provides a great opportunity to analyze the system and individual banks and needs further development.

\section{Objectives}

The purpose of the article is to study the qualitative characteristics of the Ukrainian banking system, the consequences of changes in the substantial quantitative reduction of banks in recent years, and the definition of structural and functional groups with a stable financial status. Structural-functional analysis allows not only to analyze the actual level of financial stability of each bank, but also to develop scenarios for their development, to determine their consequences, to predict the place of the bank in the market of banking services, to study the degree of risks inherent in their activities. The dynamics of the reduction of market players in 2015-2017 has affected the qualitative characteristics of the system and individual banks, which are detailed in the article. After reducing the market of banking services, it is extremely important to assess the current state, overcome the structural imbalances in the system, and establish conditions and rules for supporting its most effective elements. Formalized apparatus structural-functional analysis of the isolation of homogeneous banking groups provides a wide range of opportunities to make informed decisions in the banking regulation and supervision system and to promote the strengthening of banks.

\section{Methods}

We use the published financial statements of Ukrainian banks for 2009-2017, which is posted on the website of the National Bank of Ukraine periodically once a quarter. Based on the reported data, system indicators are calculated - indicators, which form the clusters of the self-organized map of Kohonen and structural and functional groups. Worked variants of use of different groups system indicator. Comparing the results of grouping banks on various options indicates that the successful selection of the system of indicators ensures the adequacy of assessing the specifics of banking profiles of risks, identifying their internal properties, the place in the banking services market. An important advantage of the Kohonen self-organized map is the possibility of considering a significant number of system indicators for the formation of homogeneous groups of banks and the absence of influence of any subjective factors. Published quarterly accounts of banks provide an opportunity to calculate the share of the main components of assets, liabilities, income and expenses for each bank and combine the value of 23 structural indicators in a large database.

To build maps used software Viscovery self-organized map Kohonen ine. A multidimensional data array is represented in a two-dimensional space as a self-organized Kohonen map. In clusters are similar in importance to the structural indicators of "images" of banks at different reporting dates. Close objects are in separate clusters. The geographic distance between any points on the Kohonen self-organized map is a degree of similarity between their financial indicators, that is, the characteristics of business models and the profile of risks. The input is as shown in Table 1.

Table 1. Structure input for self-organized Kohonen maps

\begin{tabular}{|l|l|l|l|l|}
\hline Reporting date & Banks & Structural indicators & & \\
\hline Date 1 & Bank 1 & & & \\
\cline { 2 - 5 } & Bank 2 & & & \\
\cline { 2 - 5 } & $\ldots$ & & & \\
\hline Date 2 & Bank 1 & & & \\
\hline & Bank 2 & & & \\
\hline & Banks & & & \\
\hline
\end{tabular}

Structural-functional analysis study is conducted quarterly and consists of 5 stages:

calculation of the system indicator for the reporting of all operating banks to another reporting date, supplementing the database and building a self-organized map Kohonen Analysis of the obtained clusters, comparing the structure of the map with the previous, estimating the average values of the system indicator for each cluster, the combination of separate close clusters in the structural and functional groups;

investigation of changes in the characteristics of structural functional groups, their position on the Kohonen self-organizing map and the size, interpretation of changes at the macro level;

investigation of changes in the characteristics of each bank, its trajectory on the Kohonen self-organized map, the close position to the location of banks liquidated in previous periods, possible simulation of the level of financial stability, and the trajectory of its transfer to the Kohonen self-organized map with changes in the system indicator (stress testing), interpretation changes at macro level; 
summarizing the state of the banking system, the reasons for the withdrawal of banks, redistribution of banking services.

\section{Results}

\section{Selection and calculation of key finanal of system indicator parameters}

A key requirement for determining the criterial basis for the isolation of groups of banks is the choice of the most significant structural and functional characteristics that characterize the distribution of key aggregates of assets and liabilities, source of profit, specialization in the market of banking services, the ratio of the main types of bank risks, etc.

The main component of banking assets - a loan and investment portfolio, which serves as a source of interest income, which forms the basis of bank profits. According to the structural ratios of the share of loans and securities, key elements of the interest policy, which consists in managing the volume of operations of allocation of resources and the level of their profitability, can be estimated. The share of consumer loans in the portfolio provides an important qualitative characteristic of the bank's business model. The share of loans of the interbank market allows to allocate banks that do not have a developed loan-deposit portfolio and provide interbank loans with a relatively low yield. Among the banks with a high placement in the interbank market, there are those that provide the equilibrium of assets and liabilities in terms of currencies through counterplacement operations and the attraction of resources in different currencies.

Non-interest-bearing highly liquid assets of the bank are an important component of assets that characterizes the level of liquidity. Their optimal size is determined by the overall structure and quality of the components of assets and liabilities. For banks that are in the structural and functional groups of high-liquid assets, it is important to analyze the causes of persistent deviations and to investigate the necessary steps to restore sustainable development. Persistent surplus highly liquid assets may indicate a lack of development of transactions that provide interest income and significant volumes of cash transactions and increased risks of legalization and laundering of proceeds of the proceeds of a criminal proceeding.

Non-operating assets that do not generate income and do not support liquidity also serve as a necessary component of the bank's assets (fixed assets, intangible assets, accounts receivable, problematic non-interest loans, borrowed loans, etc.). Significant volumes of immobilization of assets complicate the management process and lead to the need to raise interest rates on working assets. Such banks need adequate regulatory measures to control the quality of assets, the adequacy of established reserves for credit risks.

The distribution of constituent liabilities also contains the characteristics characteristic for each group. In the structure of the liabilities of most banks, the interest resources attracted from clients predominate, although some banks may have a significant share of other funds, such as accounts payable, funds paid for unregistered authorized capital, etc. The structure of the resource base affects its value and indirectly determines the return on assets.

The analysis of dynamic series of bank reporting has shown that the level of interest rates plays an important role in the structural and functional specialization of each bank, determining its place in the market of banking services. Interest rate policy largely influences the formation of structural and functional groups and reflects the characteristics of their profile of risks. The principle of structural equilibrium considers an agreed system of interest rates for all banking assets and liabilities that is subject to the bank's internal capabilities and external customer requirements.

The adequacy of capital always characterizes the level of coverage of bank risks by own funds, the ability of shareholders to compensate for possible losses in the process of activity. A higher level of capital indicates a higher level of financial sustainability protection. For the banking system of Ukraine there is a reverse relationship between the level of capital adequacy and the scale of the bank. Small banks have a surplus of capital because they are not able to provide significant development of operations and asset growth. The volume of own funds to borrowed liabilities or placed assets is always much larger than that of large systemic banks.

When forming a bank profit along with its main components, interest income and expenses, other items of income and expenses participate, among which a large amount, as a rule, has administrative and operating expenses. In recent years, the main expense of banks is the formation of reserves for credit risks. The appropriate system indicator affects the identification of banks with the biggest problems in their activities. 
Structural-functional analysis is sensitive to changes in the system of indicators, but not all of them equally affect the result of the distribution of banks. The process of forming a self-organized Kohonen map, which is implemented using the Viscovery software product, is a self-organized map of Kohonen ine, which allows you to evaluate the degree of influence of each indicator of the system indicator system on the map formation (the most important indicators are first given in Table 2 with the values of the system indicator for each structural and functional group of banks The table provides a list of 23 structural indicators in the order of reducing their impact on the distribution of banks into groups.

Table 2. Selection of structural indicators for the formation of a self-organizing Kohonen map in order of decreasing the influence on the topology

\begin{tabular}{|l|l|l|}
\hline$№$ & CI & Content \\
\hline 1 & nom & Ranking number by asset size \\
\hline 2 & VL & The ratio of the gap between assets and liabilities in foreign currency to total assets \\
\hline 3 & CA & Balance sheet equity ratio \\
\hline 4 & ROA & Return on assets \\
\hline 5 & RA & The ratio of credit risk provisions to assets \\
\hline 6 & VA & Share of foreign currency assets in total assets \\
\hline 7 & PM & Net interest margin \\
\hline 8 & SPUP & Share of current funds of legal entities in liabilities \\
\hline 9 & SPM & The share of interbank loans in liabilities \\
\hline 10 & SPFS & Share of time funds of individuals in liabilities \\
\hline 11 & SPP & Share of interest obligations in the total amount of liabilities \\
\hline 12 & PV & Value of interest obligations \\
\hline 13 & SAV & Share of highly liquid assets in assets \\
\hline 14 & SAU & Share of corporate loans in assets \\
\hline 15 & SAF & Share of consumer loans in assets \\
\hline 16 & KD & The ratio of commission income to assets \\
\hline 17 & SPFP & Share of current funds of individuals in liabilities \\
\hline 18 & SPUS & Share of fixed assets of legal entities in liabilities \\
\hline 19 & SAM & The share of interbank loans in assets \\
\hline 20 & PD & Return on interest-bearing assets \\
\hline 21 & SAC & Share of assets in assets \\
\hline 22 & TDC & The ratio of income from operations with securities to assets \\
\hline 23 & TDV & The ratio of income from operations with currency to assets \\
\hline
\end{tabular}

The selected system of criteria allows you to compare the main structural parameters: the level of capitalization, quality and constituent assets, liabilities, features of interest policy, revenue management, expenditure. The Kohonen self-organized map also simulates the level of financial stability of each bank, the trajectory of moving it between groups and assessing the relationship with these groups. The system indicator allows groups to group according to the characteristics of the main risks of loss of financial stability that are relevant for the implementation of supervisory procedures.

Investigation of various variants of map making using sufficiently detailed system indicators showed that the configuration of the group of banks on the map is stored for a long time, and changes in the structural and functional characteristics of each group demonstrate objectively existing differences between these groups. The research has been conducted since 2003, but due to the change in the presentation of financial reporting indicators since 2009, the creation of a database for building a self-organized Kohonen map, which is presented in the article, begins in 2009.

Conclusions on the financial condition of banks, obtained by traditional methods of analysis of the financial state, are consistent with the results of the isolation of structural and functional groups. For example, any bank always changes the trajectory on the map when applying measures of banking supervision or significant changes in the management system of the bank itself. It was also found that banks with affiliated shareholders tended to be in the same group at a short distance on the Kohonen self-organized card.

The list of structural indicators can be expanded and refined at the exit from the limits of the published reporting of banks and the use of statistical reporting data of banks used by banking supervision. Among them, important information is given by the classification of loans by risk groups, their concentration, the amount of arrears on accrued unpaid interest, the structure of assets and liabilities in terms of currencies, gap-by-line breaks, etc. Information about the financial condition of banks, which is collected by means of statistical reporting, belongs to the category of confidential and is not subject to widespread dissemination, as opposed to the indicators of the published financial reporting of banks used in the structural and functional analysis. 
Analysis of the state of the banking system of Ukraine by the method of structural-functional analysis on 01.01.2012. Using the system indicator system using the Viscovery software, the self-organized Kohonen ine map, according to data from 01/01/2009 to 01/01/2012, constructed the map presented in Fig. 1. The distribution of the number of banks and the aggregate amounts of their assets between clusters and structural and functional groups is given in Table 3. To characterize the state of the banking system for a specific date, not only the placement of banks on the map, but also the size of the assets of the respective banks is important. Increased attention to banking supervision requires groups with a large number of banks and with large aggregate assets.

Information about the distribution of specific banks is presented in Annex 1. Average values of individual system indicator are shown in Table 4. It should be emphasized that the formation of groups was carried out not on the individual values of the system indicator, but taking into account all their values, the Euclidean distance between the point of stay of a particular bank in 23-dimensional values of the indicators and the center of the cluster with the parameters given in Table 4. The program of forming a self-organized map Kohonen automatically allocates the cluster centers as the most distant points and displays the All banks of each cluster are placed on a two-dimensional map, such as a geographic map.

The distribution of banks as of January 1, 2012 was quite typical for most self-organizing Kohonen cards built since the beginning of 2009. The central part of the card was held by banks with average values of structural indicators, without significant differences in the structure of assets, liabilities, income and expenses. Banks included in clusters 1 and 3, marked on the map center can be considered the most balanced indicators. The cluster 1 differs from 3 more shares in national currency in the structure of assets and liabilities. Separate banks of clusters 1 and 3 got to the center only for a short time, therefore the final distribution between the groups is carried out after a detailed study of the trajectories of all banks, the duration of stay in clusters, and the features of their structural and functional characteristics. The final distribution of banks by structural and functional groups as of 01.01.2012 is given in Appendix 2. Table 5 shows the distribution of banks by groups after studying their trajectories.

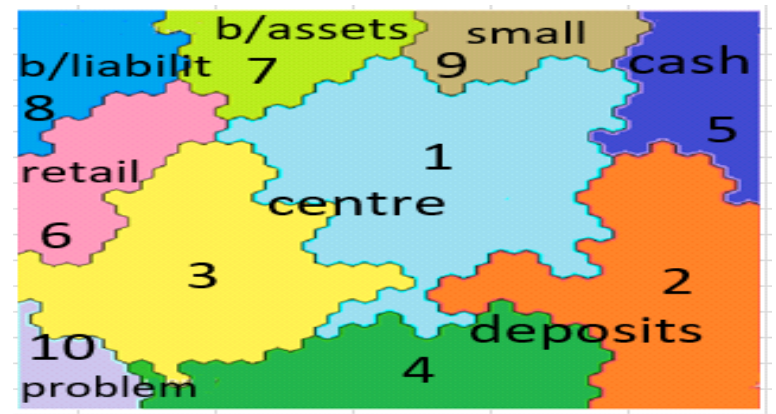

Figure 1 Distribution of banks by self-organized card Kohonen as of 01.01.2012

Table 3. Initial distribution of banks between clusters and structural and functional groups as at 01/01/2012

\begin{tabular}{|l|c|c|c|}
\hline \multicolumn{1}{|c|}{ Cluster } & Group & Number of banks & Assets, mln \\
\hline 1 & centre & 30 & 45736 \\
\hline 3 & centre & 28 & 653928 \\
\hline 2 & deposits/private & 24 & 22936 \\
\hline 4 & deposits/private & 20 & 46347 \\
\hline 5 & cash & 16 & 19186 \\
\hline 6 & retail & 12 & 25078 \\
\hline 7 & bank/assets & 15 & 735460 \\
\hline 8 & bank/liabilities & 12 & 4191 \\
\hline 9 & small/captive & 11 & 39676 \\
\hline 10 & problem banks & 7 & 1054272 \\
\hline
\end{tabular}

Table 4. Comparison of the System Indicator values of individual clusters as of 01.01.2012

\begin{tabular}{|l|c|c|c|c|c|c|c|c|c|c|c|c|}
\hline Cluster & nom & VL & SPM & SAC & VA & ROA & CA & RA & SAU & SAF & SAV & SAM \\
\hline C 1 & 110.5 & $30.3 \%$ & $23.8 \%$ & $5.1 \%$ & $-0.7 \%$ & $0.2 \%$ & $23.8 \%$ & $6.2 \%$ & $50.2 \%$ & $12.3 \%$ & $10.8 \%$ & $16.1 \%$ \\
\hline C 2 & 115.4 & $21.9 \%$ & $11.6 \%$ & $4.4 \%$ & $-0.7 \%$ & $-1.0 \%$ & $24.7 \%$ & $7.4 \%$ & $55.8 \%$ & $21.0 \%$ & $10.7 \%$ & $4.2 \%$ \\
\hline C 3 & 32.2 & $41.4 \%$ & $29.3 \%$ & $5.4 \%$ & $-3.4 \%$ & $-1.8 \%$ & $13.9 \%$ & $10.1 \%$ & $58.7 \%$ & $17.6 \%$ & $13.6 \%$ & $5.7 \%$ \\
\hline
\end{tabular}


Table 4 (cont.). Comparison of the System Indicator values of individual clusters as of 01.01.2012

\begin{tabular}{|l|c|c|c|c|c|c|c|c|c|c|c|c|}
\hline C 4 & 91.8 & $20.4 \%$ & $22.7 \%$ & $2.0 \%$ & $-1.3 \%$ & $-0.2 \%$ & $26.8 \%$ & $8.1 \%$ & $70.9 \%$ & $11.9 \%$ & $11.1 \%$ & $5.6 \%$ \\
\hline C 5 & 126.1 & $22.7 \%$ & $7.9 \%$ & $7.4 \%$ & $1.2 \%$ & $0.6 \%$ & $38.8 \%$ & $6.3 \%$ & $43.7 \%$ & $10.1 \%$ & $28.4 \%$ & $10.4 \%$ \\
\hline C 6 & 57.7 & $48.0 \%$ & $31.4 \%$ & $3.9 \%$ & $-3.7 \%$ & $-0.9 \%$ & $17.5 \%$ & $11.7 \%$ & $21.1 \%$ & $56.9 \%$ & $13.2 \%$ & $7.3 \%$ \\
\hline C 7 & 104.6 & $46.1 \%$ & $51.4 \%$ & $2.6 \%$ & $-0.6 \%$ & $0.3 \%$ & $21.8 \%$ & $5.3 \%$ & $27.1 \%$ & $8.8 \%$ & $16.3 \%$ & $39.3 \%$ \\
\hline C 8 & 41.6 & $63.0 \%$ & $61.9 \%$ & $7.0 \%$ & $-3.0 \%$ & $-1.5 \%$ & $14.9 \%$ & $9.9 \%$ & $45.1 \%$ & $28.7 \%$ & $15.5 \%$ & $3.8 \%$ \\
\hline C 9 & 146.9 & $24.2 \%$ & $7.5 \%$ & $5.2 \%$ & $-0.5 \%$ & $-0.6 \%$ & $41.6 \%$ & $7.4 \%$ & $36.1 \%$ & $13.4 \%$ & $19.0 \%$ & $8.2 \%$ \\
\hline C 10 & 84.8 & $22.0 \%$ & $34.8 \%$ & $12.1 \%$ & $-19.0 \%$ & $-103.8 \%$ & $-26.4 \%$ & $71.0 \%$ & $82.2 \%$ & $33.7 \%$ & $4.4 \%$ & $3.0 \%$ \\
\hline
\end{tabular}

A significant part of most cards traditionally was occupied by a group of deposits / private with increased fixed-term liabilities of individuals. As of 01.01.2012, the group combines clusters 2 and 4. Usually deposits / private group includes small banks, which causes small aggregate assets with the largest number of banks. The retail group (cluster 6) consists of banks that specialize in consumer lending, bank / group banks / liabilities (cluster 8) have an increased share of interbank liabilities, as a rule, support of foreign shareholders through interbank loans. The cash group (cluster 5) is characterized by excessive highly liquid assets and current liabilities, increased operational risks when dealing with cash. The small / captive group (cluster 9) has differences in the structure of the resource base, an increased share of so-called "other" liabilities that are not funds of individuals, legal entities or the interbank market. Banks of the small / captive group, as a rule, are small banks associated with the business of their shareholders. The bank / assets group (cluster 7) also combines small banks with a high proportion of interbank assets, which places resources on the interbank market more than other banks. Some clusters traditionally formed on most Kohonen self-organizing maps are absent on the map, built on 01/01/2012. Even if a certain group is absent for a specific date on the map, structural and functional characteristics of banks are estimated on their trajectories and can be assigned to this group. Among the following groups, the following three should be identified. In the structure of obligations of the banks of the corporate / liabilities group, the term funds of legal entities are dominated by the group current accounts - current funds of individuals. The investment group with a significant share of assets in securities has a tendency to increase during the period under investigation. Finally, a group of troubled banks with significant losses and poor-quality assets, increased reserves for credit risk, is referred to as problem banks (cluster 10).

Table 5. The final distribution of banks between structural and functional groups as of 01.01.2012

\begin{tabular}{|l|c|c|c|}
\hline № & Group & Number of banks & Assets, mln \\
\hline 1 & centre & 36 & 387710 \\
\hline 2 & deposits/private & 41 & 14777 \\
\hline 3 & cash & 18 & 286347 \\
\hline 4 & retail & 16 & 28771 \\
\hline 5 & small/captive & 15 & 171026 \\
\hline 6 & bank/liabilities & 14 & 89943 \\
\hline 7 & investment & 10 & 8613 \\
\hline 8 & bank/assets & 9 & 7952 \\
\hline 9 & corporate/liabilities & 8 & 24289 \\
\hline 10 & problem banks & 8 & 1054272 \\
\hline
\end{tabular}

Analysis of the state of the banking system of Ukraine as of 10.01.2017. For the construction of the selforganizing Kohonen card on 10.01.2017, data from banks' reporting for the period from 01.01.2009 to 10.01.2017 have been used. The general view of the map is shown in Fig. 2, information on the previous distribution of banks by groups - in Table 6 , the final table 7, the value of the system indicator of the received clusters - in Table 8. According to Annex 3, a list of banks by clusters and groups is given for the analysis of trajectories, in Appendix 4, the final distribution Banks by groups on 01.10.2017.

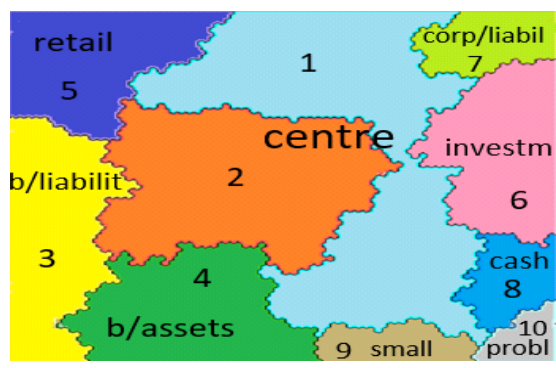

Fig. 2 Distribution of banks by self-organized card Kohonen on 01.01.2012 
Table 6. Initial distribution of banks between clusters and structural-functional groups on 10.01.2017

\begin{tabular}{|l|c|c|c|}
\hline \multicolumn{1}{|c|}{ Claster } & Group & Number of banks & Assets, mln. hrn. \\
\hline 1 & centre & 12 & 10833.5 \\
\hline 2 & centre & 13 & 119177.3 \\
\hline 6 & investment & 41 & 22838.6 \\
\hline 10 & investment & 8 & 72032.8 \\
\hline 3 & bank/liabilities & 4 & 7282.1 \\
\hline 4 & bank/assets & 4 & 46136.4 \\
\hline 5 & retail & 5 & 162.9 \\
\hline 8 & cash & 1 & 907.5 \\
\hline 9 & small/captive & 3 & 1298936.1 \\
\hline \multicolumn{2}{|l|}{} \\
\hline
\end{tabular}

Table 7. Comparison of the individual cluster system indicator on 01.10.2017

\begin{tabular}{|l|l|l|l|l|l|l|l|l|l|l|l|l|l|}
\hline Cluster & nom & VL & CA & ROA & RA & VA & SPM & SPFS & SAV & SAU & SAF & SAM & SAC \\
\hline C 1 & 110.9 & $22.90 \%$ & $24.30 \%$ & $-9.30 \%$ & $11.20 \%$ & $4.30 \%$ & $9.39 \%$ & $39.80 \%$ & $13.10 \%$ & $60.90 \%$ & $10.20 \%$ & $3.86 \%$ & $4.34 \%$ \\
\hline C 2 & 45.7 & $38.70 \%$ & $14.10 \%$ & $-0.80 \%$ & $8.70 \%$ & $1.90 \%$ & $16.57 \%$ & $35.30 \%$ & $12.60 \%$ & $63.90 \%$ & $7.60 \%$ & $5.62 \%$ & $4.36 \%$ \\
\hline C 3 & 50.1 & $40.20 \%$ & $22.00 \%$ & $-3.40 \%$ & $18.60 \%$ & $-3.00 \%$ & $53.31 \%$ & $16.00 \%$ & $14.70 \%$ & $54.40 \%$ & $11.30 \%$ & $4.88 \%$ & $7.40 \%$ \\
\hline C 4 & 109.4 & $38.70 \%$ & $21.50 \%$ & $-0.30 \%$ & $6.80 \%$ & $1.20 \%$ & $31.39 \%$ & $27.10 \%$ & $10.60 \%$ & $37.00 \%$ & $8.20 \%$ & $25.62 \%$ & $4.63 \%$ \\
\hline C 5 & 59.6 & $39.60 \%$ & $16.90 \%$ & $-1.30 \%$ & $13.30 \%$ & $3.30 \%$ & $25.34 \%$ & $31.40 \%$ & $13.40 \%$ & $25.90 \%$ & $46.70 \%$ & $4.86 \%$ & $4.59 \%$ \\
\hline C 6 & 54.5 & $33.60 \%$ & $22.30 \%$ & $-0.40 \%$ & $11.00 \%$ & $2.00 \%$ & $7.79 \%$ & $23.00 \%$ & $17.20 \%$ & $39.40 \%$ & $8.30 \%$ & $5.33 \%$ & $19.59 \%$ \\
\hline C 7 & 125.4 & $9.50 \%$ & $43.30 \%$ & $0.00 \%$ & $10.90 \%$ & $0.30 \%$ & $4.97 \%$ & $16.00 \%$ & $9.90 \%$ & $76.50 \%$ & $3.40 \%$ & $2.45 \%$ & $2.97 \%$ \\
\hline C 8 & 126 & $21.20 \%$ & $43.00 \%$ & $0.60 \%$ & $5.80 \%$ & $1.80 \%$ & $7.16 \%$ & $12.60 \%$ & $39.20 \%$ & $39.80 \%$ & $3.70 \%$ & $9.49 \%$ & $3.89 \%$ \\
\hline C 9 & 131.1 & $15.60 \%$ & $53.10 \%$ & $11.70 \%$ & $20.30 \%$ & $0.30 \%$ & $3.97 \%$ & $4.40 \%$ & $23.30 \%$ & $29.20 \%$ & $8.30 \%$ & $7.83 \%$ & $7.49 \%$ \\
\hline C 10 & 80.5 & $18.20 \%$ & $42.00 \%$ & $0.30 \%$ & $7.60 \%$ & $1.90 \%$ & $5.93 \%$ & $4.10 \%$ & $13.50 \%$ & $23.50 \%$ & $0.70 \%$ & $5.36 \%$ & $46.69 \%$ \\
\hline
\end{tabular}

Table 8. The final distribution of banks between structural and functional groups as of 10/01/2017

\begin{tabular}{|l|c|c|c|}
\hline № & Group & Number of banks & Assets. mln \\
\hline 1 & investment & 30 & 1006678.2 \\
\hline 2 & centre & 10 & 95688.9 \\
\hline 3 & bank/liabilities & 7 & 89422.4 \\
\hline 4 & retail & 4 & 41120.5 \\
\hline 5 & current accounts & 9 & 22744.2 \\
\hline 6 & cash & 10 & 11955.9 \\
\hline 7 & deposits/private & 10 & 9126.2 \\
\hline 8 & small/captive & 6 & 3035.9 \\
\hline 9 & problem banks & 5 & 19163.9 \\
\hline & Total in the system & 91 & 1298936.1 \\
\hline
\end{tabular}

Comparison of information about the distribution of banks to groups shows a significant reduction of the group center and the growth of the number of banks with a high share of securities in assets - the investment group. Migration of banks to new groups is conditioned by systemic structural transformations that have appeared in the increase of the respective groups, as well as changes in the internal characteristics of individual banks.

Structural-functional transformations in the banking system of Ukraine in the period from January 1, 2012 to October 1, 2017. Table 9 shows the redistribution of banks for the incomplete six years. The initial structure of the system as of January 1,2012 is considered as the base, the newly created banks for this period are not taken into account, nor does it take into account the change in the size of assets of each bank, but only investigates the migration of banks between groups, its causes and consequences. During the research period, 85 banks were liquidated, assets of which accounted for $25 \%$ of the system assets. One fifth of banks remained in the same group as in the beginning of the investigated period. 
Table 9. Migration of banks for the period from 01.01.2012 to 10.01.2017

\begin{tabular}{|c|c|c|c|c|c|c|c|c|c|c|c|}
\hline \multirow[b]{2}{*}{ № } & \multirow[b]{2}{*}{ Group } & \multicolumn{2}{|c|}{01.01 .2012} & \multicolumn{2}{|c|}{ Remaining } & \multicolumn{2}{|c|}{ Eliminated } & \multicolumn{2}{|c|}{$\begin{array}{ll}\text { To } & \text { Investment } \\
\text { Group } & \\
\end{array}$} & \multicolumn{2}{|l|}{ Others } \\
\hline & & $\begin{array}{l}\text { Number } \\
\text { of banks }\end{array}$ & $\begin{array}{c}\text { Assets, } \\
\text { billion } \\
\text { hrn. }\end{array}$ & $\begin{array}{l}\text { Number } \\
\text { of banks }\end{array}$ & $\begin{array}{c}\text { Assets, } \\
\text { billion } \\
\text { hrn. }\end{array}$ & $\begin{array}{l}\text { Number } \\
\text { of banks }\end{array}$ & $\begin{array}{c}\text { Assets, } \\
\text { billion } \\
\text { hrn. }\end{array}$ & $\begin{array}{l}\text { Number } \\
\text { of banks }\end{array}$ & $\begin{array}{c}\text { Assets, } \\
\text { billion } \\
\text { hrn. }\end{array}$ & $\begin{array}{l}\text { Number } \\
\text { of banks }\end{array}$ & $\begin{array}{c}\text { Assets, } \\
\text { billion } \\
\text { hrn. }\end{array}$ \\
\hline 1 & Centre & 36 & 388 & 8 & 52 & 20 & 132 & 6 & 200 & 2 & 4 \\
\hline 2 & Deposits/private & 41 & 35 & 5 & 3 & 26 & 25 & 2 & 2 & 8 & 5 \\
\hline 3 & Cash & 18 & 15 & 5 & 3 & 8 & 4 & 2 & 4 & 3 & 4 \\
\hline 4 & Retail & 16 & 286 & 4 & 45 & 4 & 28 & 6 & 205 & 2 & 9 \\
\hline 5 & Small/captive & 15 & 29 & 4 & 1 & 7 & 13 & 1 & 8 & 3 & 7 \\
\hline 6 & Bank/liabilities & 14 & 171 & 5 & 99 & 3 & 43 & 5 & 27 & 1 & 2 \\
\hline 7 & Investment & 10 & 90 & 5 & 86 & 5 & 4 & & & & \\
\hline 8 & Bank/assets & 9 & 9 & & & 4 & 5 & & & 5 & 4 \\
\hline 9 & Corporate/liabilities & 8 & 8 & & & 8 & 8 & & & & \\
\hline 10 & Problem banks & 8 & 24 & & & & & & & & \\
\hline & & 175 & 1054 & 36 & 288 & 85 & 262 & 22 & 446 & 24 & 34 \\
\hline
\end{tabular}

The migration of banks from the center group reflects significant systemic changes, since at the beginning of the study period, this group was the largest in aggregate assets. Out of 36 banks with aggregate assets of UAH 388 billion, which were in the central part of the study initially, only 8 banks with assets of 52 billion UAH. remained in this group in 2017. The largest banks moved to the investment group, withdrawing from the market $56 \%$ of the banks group center. The final allocation of banks to groups is presented in Appendix 4. The center group includes large, medium and small banks, both with foreign and Ukrainian capital. It is the central group that defines a set of financially balanced banks with positive development forecasts. At the same time, it is necessary to carefully study the ownership structure of banks, because it is the lack of transparency of capital and the reason for withdrawal from the market of a significant number of banks.

Table 10 shows the list of liquidated banks that were part of the central group at the beginning of the investigated period.

Table 10. Banks of the center group as of 01.01.2012, which were liquidated before 01.10.2017

\begin{tabular}{|c|c|c|c|c|}
\hline № & Bank & Assets, UAH thousand. & Year of liquidation & Last group \\
\hline 1 & Finansy, Kredyt & 22607223 & 2014 & currency losses \\
\hline 2 & Brokbiznesbank & 19965357 & 2014 & currency losses \\
\hline 3 & Forum & 12120969 & 2014 & currency losses \\
\hline 4 & Aktabank & 4382835 & 2014 & centre \\
\hline 5 & Aktyv - Bank & 3521900 & 2014 & centre \\
\hline 6 & Kredytprombank & 12760835 & 2015 & currency losses \\
\hline 7 & Ukrainskyi Profesiinyi Bank & 3216379 & 2015 & currency losses \\
\hline 8 & Kyivska Rus & 5314845 & 2015 & centre \\
\hline 9 & Zlatobank & 3289512 & 2015 & centre \\
\hline 10 & Vieibi Bank & 9438931 & 2015 & deposits/private \\
\hline 11 & Imeksbank & 8502586 & 2015 & deposits/private \\
\hline 12 & Ekspobank & 2215632 & 2015 & deposits/private \\
\hline 13 & Bh Bank & 1818734 & 2015 & deposits/private \\
\hline 14 & Kambio & 2200698 & 2015 & investment \\
\hline 15 & Khreshchatyk & 8868445 & 2016 & centre \\
\hline 16 & Ukrinbank & 4472918 & 2016 & centre \\
\hline 17 & Vseukrainskyi Bank Rozvytku & 1686195 & 2016 & current accounts \\
\hline 18 & Finansova Initsiatyva & 9977155 & 2017 & small/captive \\
\hline 19 & Finbank & 2213098 & 2017 & small/captive \\
\hline \multirow[t]{2}{*}{20} & Diamantbank & 2668541 & 2017 & centre \\
\hline & Total & 141242788 & & \\
\hline
\end{tabular}

A significant number of banks remaining in the central group until the moment of termination of activity was liquidated due to the opaque ownership structure. Some banks, liquidated at different periods from different groups, had increased operational risks or violated the legislation on financial monitoring. In most cases, the situation in a group indicates the existence of problems in the activity. For example, banks that went ahead of the liquidation of the deposits / private group with increased fixed-term liabilities of individuals in 2015 experienced liquidity shortages, and banks that migrated to a small / sective group in 2017 tried to maintain liquidity at the expense of shareholder resources.

The largest liquidated banks of the central group were withdrawn from the market in the early stages of the socalled "purification" of the banking system in connection with high losses from foreign exchange purchase and sale operations. During this period, a separate group of banks with a loss-making result of foreign exchange operations was formed on the Kohonen self-organizing card. It should be emphasized that it was during periods 
of a sharp fall in the hryvnia that the accelerated reduction in aggregate liabilities and assets and the transition of banks of various structural and functional groups to currency losses and subsequent withdrawal from the market. The group of loss-making banks, currency losses over the years 2014-2016, several times significantly increased. The distribution of banks in the 2nd quarter of 2014 was determined by the reaction of banks to the jump in the national currency (from 8 to 11 USD for $1 \mathrm{UAH}$ ). Among the liquidated in this period banks of different groups a high proportion of those belonging to the group's currency losses or having an address in the Crimea and Donetsk.

In the following third quarter, the number of banks in groups formed on the basis of the results of operations with currency, somewhat decreased and began to grow the group of current accounts with a large share of current funds in liabilities. The group of current accounts in this period switched over to individual large banks with foreign shareholders who had previously had great support from parent banks and belonged to the bank / liabilities group: Ukrsotsbank, Ukrsibbank, Otp Bank, Prokredit Bank, Bta Bank, Raiffeisen Bank Aval, Alpha Bank, Pravex-Bank, Kredobank and others. The growth of the bank / liabilities group in the third quarter of 2014 has characterized the movement of clients' funds from liquidated to large banks, usually with foreign shareholders, and preferential placement on current accounts.

Thus, the first structural transformation in the system appeared in 2014 due to a significant increase in the number of banks in the current accounts group, whose resource base has a higher share of current funds of individuals. Some large banks have crossed over to the group. The maximum value (52 banks out of 130) was achieved as of 10/01/2015, after which the group decreased, but continued to include large banks. From the middle of 2015, there are signs of excess liquidity of banks, reorientation of resources to cash on demand, operations - from loans to short-term, aimed at commission income. The number of banks with high highly liquid assets is increasing. For banks specializing in cash operations, operational risks and the likelihood of violations of financial monitoring legislation increase.

Starting from 2015, a group of investments with a high share of securities in assets is growing. The state and individual large banks with foreign shareholders that have attracted current assets of individuals place assets in government securities. Bank lending operations have shrunk. To date, a significant number of borrowers has an increased credit burden or insufficient solvency and is limited by too high lending rates. In high credit risks, low demand for expensive loans does not encourage banks to cheapen them. Most banks have accumulated non-performing loans and serve inactive assets. The largest Privatbank, which after the nationalization has a stable position in this group, like all state-owned banks, switched to the investment group.

The group of deposits / private with increased fixed-term liabilities of individuals at the beginning of 2012 was the largest in number of banks, but not in size of assets. As shown in Table 9, out of 41 banks, twenty five have been liquidated, only five remained in the initial group. Banks permanently in the deposit / private group are usually small in terms of assets and capital. The resource base of these banks is the most expensive, the activities are not sufficiently effective. Banks are at increased risk of insufficient capitalization for operations.

Table 11 lists the liquidated banks that were part of the deposit / private group in 2012. Most of these banks were liquidated in the first two years of the so-called "clearing" of the banking system and were in the deposit / private group until the time of liquidation. The reason for the withdrawal of most banks from the market was the problem of liquidity, opaque ownership structure or placement of banks in Donetsk and Crimea (in the temporarily occupied territory).

Table 11. Banks of the deposits / private group as of 01.01.2012, which were liquidated before 01.07.2017

\begin{tabular}{|c|c|c|c|c|}
\hline № & Bank & $\begin{array}{c}\text { Assets, UAH } \\
\text { thousand. }\end{array}$ & Year of liquidation & Last group \\
\hline 1 & Avtokrazbank & 1244649 & 2014 & deposits/private \\
\hline 2 & Zoloti Vorota & 1513391 & 2014 & deposits/private \\
\hline 3 & Promekonombank & 559842 & 2014 & deposits/private \\
\hline 4 & Finrostbank & 880107 & 2014 & deposits/private \\
\hline 5 & Starokyivskyi Bank & 656047 & 2014 & deposits/private \\
\hline 6 & Ukrainskyi Finansovyi Svit & 1204603 & 2014 & deposits/private \\
\hline 7 & Ukrkomunbank & 605591 & 2014 & deposits/private \\
\hline 8 & Merkurii & 1893737 & 2014 & currency losses \\
\hline 9 & Chornom.Bank Rozv.Ta Rekonstr. & 676728 & 2014 & currency losses \\
\hline 10 & Zakhidinkombank & 923113 & 2014 & currency losses \\
\hline 11 & Demark & 1979866 & 2015 & deposits/private \\
\hline 12 & Lehbank & 394315 & 2015 & deposits/private \\
\hline 13 & Aksioma & 439238 & 2015 & deposits/private \\
\hline 14 & Natsionalnyi Kredyt & 1016385 & 2015 & deposits/private \\
\hline
\end{tabular}


Table 11 (cont.). Banks of the deposits / private group as of 01.01.2012, which were liquidated before 01.07.2017

\begin{tabular}{|c|c|c|c|c|}
\hline 15 & Stolychnyi & 302656 & 2015 & deposits/private \\
\hline 16 & Natsionalni Investytsii & 2369041 & 2015 & deposits/private \\
\hline 17 & Kapital & 1245897 & 2015 & deposits/private \\
\hline 18 & Kontrakt & 788271 & 2015 & deposits/private \\
\hline 19 & Radykal Bank & 812091 & 2015 & deposits/private \\
\hline 20 & Soiuz & 5293564 & 2015 & centre \\
\hline 21 & Enerhobank & 2109908 & 2015 & currency losses \\
\hline 22 & Investbank & 574118 & 2016 & centre \\
\hline 23 & Klasykbank & 576218 & 2016 & deposits/private \\
\hline 24 & Finans Bank & 162515 & 2016 & small/captive \\
\hline \multirow[t]{2}{*}{25} & Narodnyi Kapital & 224017 & 2017 & deposits/private \\
\hline & Усього & 21965267 & & \\
\hline
\end{tabular}

Given the large number of liquidated banks from the deposits / private group, we can state the increased risks of withdrawal from these banks, primarily due to insufficient capital.

The investment group has taken the leading position in the system as of $10 / 01 / 2017$, bringing together 30 banks with aggregate assets of 1006.7 billion hryvnias. Most investment group banks have placed assets in government securities. The relevant concentration is at increased risk and has only temporary benefits associated with the status of government guarantees. At the same time, like any concentration of assets, the structural difference between an investment group needs to be controlled in terms of the system.

The cash group at the end of the period consists of 10 banks with aggregate assets of UAH 11955 bln, which do not reach $1 \%$ of the assets of the system. According to the characteristics of migration of groups, shown in Table 9, most of the banks are withdrawn from the market. The Group is characterized by an increased share of highly liquid assets, primarily cash and current liabilities. Banks of this group usually have significant volumes of operations aimed at obtaining commission income and because of increased operational risks are exposed in violation of the legislation on financial monitoring. At the same time, to evaluate the structural and functional properties of each bank, a study of an individual trajectory is required. Most banks in the group are small, that is, they are at risk of not achieving the required level of capitalization. The liquidated banks of the Group A / u-Z / $\mathrm{n}$ are listed in Table 12. Most of them were withdrawn from the market in 2014-2015 from the same group.

Table 12. Cash groups of banks as of 01.01.2012, which were liquidated before 01.10.2017

\begin{tabular}{|l|l|c|c|c|}
\hline \multicolumn{1}{|c|}{ Bank } & \multicolumn{1}{|c|}{$\begin{array}{c}\text { Assets, Thousands, } \\
\text { UAH. }\end{array}$} & $\begin{array}{c}\text { Year Of } \\
\text { Liquidation }\end{array}$ & Last Group \\
\hline 1 & Prime-Bank & 228271 & 2014 & Cash \\
\hline 2 & East-Promysl.Komerts.Bank & 142687 & 2014 & Cash \\
\hline 3 & Grin Bank & 201112 & 2015 & Cash \\
\hline 4 & Tc Credit & 1307302 & 2015 & Cash \\
\hline 5 & Weles & 174618 & 2015 & Cash \\
\hline 6 & Profin Bank & 349302 & 2015 & Deposits/Private \\
\hline 7 & Finexbank & 422186 & 2016 & Cash \\
\hline 8 & Smartbank & 252796 & 2016 & Cash \\
\hline 9 & New & 948942 & 2017 & Cash \\
\hline & Total & 4027216 & & \\
\hline
\end{tabular}

Unlike the cash group, the retail group of banks with an increased share of individual loans occupied a significant share in the system by the size of assets at the beginning of the period, down to $27 \%$ and significantly decreased over the period, the banks with the largest assets moved to other groups. After the crisis of 2009-2010, banks with problem loans of individuals in foreign currency, which were in the retail group, were placed on the self-organized map of Kohonen next to the problem, that is, they had signs of the worst in the system. Gradually, individual banks with foreign shareholders switched to the current accounts group with a large share of current liabilities of individuals, and these banks were directed to the flows of liquidated banks. Subsequently, a significant number of large banks went to the investment group with a significant portfolio of securities. To this group were also transferred state banks that have accumulated significant volumes of domestic government bond loans in assets during capitalization. The composition of the retail group and the aggregate bank assets significantly decreased during the research period. Banks with an increased share of individual loans have poor assets and can not be considered financially sustainable. 
The financial status of banks in the bank / liabilities group is fairly stable, although the ratio of RA to assets is high. The support of foreign shareholders ensures the timely fulfillment of the requirements for the formation of reserves for credit risks. It should be noted that most European banks use conservative approaches to assessing the risks for their adequate coverage.

Separate consequences of "clearing" the banking system from 01.04.2014 to 01.01.2017. Interpreting the place of the structural and functional group of banks on the map and influencing the topology of individual indicators is an important characteristic of the system. Most structural and functional groups occupy a fixed position on the self-organized map of Kohonen for a definite period. Individual structural indicators unite groups around themselves, others do not have a single extremum, and an interpretation of their influence on the formation of the map topology needs an analysis of other indicators. There are cases when groups are formed not permanently, but only at certain periods (as a group of currency losses). A separate structural and functional group of banks is formed around the values of one or more system indicators that occupy a close position on the map. For example, a group of troubled banks is formed around the extreme values of such qualitative indicators as the ROA assets return, the ratio of the amount of loan provisions to total RA assets, as well as the ratio of capital to CA assets, the currency position VA (usually with negative values). More detailed information on structural changes in the banking system can be obtained from an analysis of the situation of individual groups on the Kohonen self-organized map.

Since the beginning of 2015, a group of troubled banks with the worst performance indicators of assets and operations has shifted from the northeast to the south-eastern corner of the map. The transition of the troubled banks segment to the northern part of the map and the steady change in their position from 2015 marks a qualitative change in the structural and functional characteristics: problem banks with losses and increased credit risks have become smaller in size, in the structure of liabilities of these banks the share of time deposits of individuals has increased, has decreased interbank loans, the share of foreign currency in assets decreased. Consumer loans continue to hold a high share in troubled banks.

At the end of 2014, large banks that attracted current assets of individuals placed a significant proportion of assets in government securities, which affected the characteristics of groups. Bank lending operations have shrunk. To date, a significant number of borrowers has an increased credit burden or insufficient solvency and is limited by too high lending rates. In high credit risks, low demand for expensive loans does not encourage banks to cheapen them. Most banks have accumulated non-performing loans and serve inactive assets.

From the middle of 2015, there are signs of excess liquidity of banks, reorientation of resources to cash on demand, operations - from loans to short-term, aimed at commission income. The number of banks with high liquid assets has increased. For banks specializing in cash operations, operational risks and the likelihood of violations of financial monitoring legislation increase.

In recent years, the amount of reserves for credit risks has increased significantly and, in the beginning of 2017, almost equaled the total volume of the loan portfolio (UAH 500 billion in reserves under UAH 570 billion). During this period, the aggregate reserves increased by 350 billion hryvnias, including reserves of Privatbank - by 150 billion hryvnias, most of reserves were created with the nationalization of the bank at the end of 2016. Over the last three years, most banks have formed reserves for credit risks at an accelerated pace, even with a slight increase or, in general, a reduction in aggregate assets. Only some banks with foreign shareholders had a relatively high level of reserves in 2014. The growth of small banks' reserves by 2017 was negligible, as most of them have not yet undergone a diagnosis of banking supervision. In general, the size of reserves grew rapidly for all banks, which affected their qualitative characteristics. During recent years, the redistribution of assets in favor of the largest banks took place. The largest increase by 178 billion hryvnias. was observed for the three largest banks with a growth of securities in Oschadbank on 41 billion hryvnias, in Ukreximbank - by 14 billion hrn.

The current state of the banking system shows the need for structural reforms: reducing the share of stateowned banks, increasing the efficiency and scale of development of banks with Ukrainian capital, expanding lending operations to the economy. The crisis has demonstrated the key role of customer confidence in the development of any bank. It is the factor of trust in state-owned banks and banks with a global brand that has caused redistribution of resources in the domestic banking system.

\section{Conclusion}

During the period of reduction of the banking system (so-called clearing) there was a redistribution of resources in favor of the largest banks. At the same time, state-owned banks took over half of the market. The first 
qualitative change of the system appeared in 2014 due to a significant increase in the number of banks in the current accounts group, whose resource base has a higher share of current funds of individuals. The growth of the current accounts group characterizes the movement of clients' money from liquidated to large state and banks by foreign shareholders, as well as preferential placement on current accounts. For the development of lending operations, banks need time resources.

Observations of structural and functional changes in the system are divided into two stages: 2014-2015 - active fall, 2016-2017 - slowed down. Many liquidated banks belonged to the group of currency losses, which is explained by the reaction of the system to the jumps in the national currency. The reason for the liquidation of many banks was increased operational risks due to significant cash transactions, non-compliance with legislation on financial monitoring. Problem banks with losses and increased credit risks have become smaller in size, in the structure of liabilities of these banks increased the share of term deposits of individuals, reduced interbank loans, the share of foreign currency decreased in assets. Consumer loans continue to hold a high share in troubled banks.

Large state banks and some daughters of foreign shareholders that have attracted current assets of individuals place assets in government securities. Bank lending operations are shrinking. A significant number of borrowers has an increased credit burden or insufficient solvency and is limited by too high lending rates. Most banks have accumulated non-performing loans and serve inactive assets.

From the middle of 2015, there are signs of excess liquidity of banks, reorientation of resources to cash on demand, operations - from loans to short-term, aimed at commission income. The number of banks with high highly liquid assets is increasing. For banks specializing in cash operations, operational risks and the likelihood of violations of financial monitoring legislation increase.

The current state of the banking system has demonstrated the key role of customer confidence in the stable operation of the entire system and the development of any bank and. The banking crisis has become a consequence of the general socio-economic instability, accumulated problems of past years, a sharp fluctuation in the exchange rate of the national currency, and so on. Banks were in the very epicenter of problems generated by the actions of the past leadership of the country, the withdrawal of foreign currency, the outflow of resources, loss of confidence of the population. After a significant reduction in the market of banking services, it is extremely important to assess the current state, overcome structural imbalances in the system, and establish conditions and rules for supporting its most effective elements. As the practice of using the method of structural and functional analysis to assess the financial stability of the system and of individual banks has demonstrated, a formalized apparatus for the separation of homogeneous banking groups provides a wide range of opportunities to make well-grounded decisions in the banking regulation and supervision system.

The Kohonen self-organized maps are based on a database that contains a variety of relative indicators calculated based on financial reporting by banks. Indicators characterize the structure of assets, liabilities, income and expenses of banks, the efficiency of activities and their place in the market of banking services. A multidimensional array of indicators can reveal the hidden properties of banks, form homogeneous groups considering all characteristics, compare the financial stability of groups and individual banks. The use of the Kohonen self-organized card allows for simultaneous consideration of various aspects of financial stability of banks, the identification of close objects on the multidimensional databases of their reporting, and to represent them in a convenient form for interpretation.

The structural-functional analysis of the banking system can be used by the National Bank of Ukraine, the main supervisory bank of Ukraine, to identify fragile banks and predict their bankruptcy. Banks can use findings to analyze their financial position system indicators.

The structural-functional analysis of the banking system considers the different aspects of the bank's financial system: credit risk, liquidity level, deposit portfolio, return on assets, interest and rate of assets and liabilities. Cluster analysis helps to allocate similar financial indicators to different clusters and to assess the financial system indicator in conjunction.

Structural-functional analysis of the banking system allows to carry out a qualitative assessment of the financial stability of the system based on the characteristics of the mutual arrangement of groups, their sizes and average values of financial indicators. The formation of groups simultaneously considers all the multidimensional values of the banks' indicators, which allows the output. 


\section{References}

1. European Central Bank, ECB (2014). Guide to banking supervision. Available at: https://www. bankingsupervision.europa.eu/ecb/pub/pdf/ssmguidebankingsupervision201411.en.pdf?807838fa2a8bb9587 49f411c432d1f3e

2. European Central Bank, ECB (2017). SSM SREP Methodology Booklet. Available at: https://www. bankingsupervision.europa.eu/ecb/pub/pdf/ssm.srep_methodology_booklet_2017.en.pdf?508ca0e386f9b913 $\underline{69820 \mathrm{bc} 927863456}$

3. Basel Committee on Banking Supervision, BCBS (2000). Principles for the Management of Credit Risk. Available at: http://www.bis.org/publ/bcbs75.pdf

4. Basel Committee on Banking Supervision, BCBS (2008). Principles for sound liquidity risk management and supervision. Available at: http://www.bis.org/publ/bcbs144.pdf

5. National Bank of Ukraine, NBU (2018). Shock Contagion, Asset Quality and Lending Behavior. Available at: https://bank.gov.ua/doccatalog/document?id=62899125

6. National Bank of Ukraine, NBU (2017). Secular Stagnation: Policy Options and the Cyclical Sensitivity in Estimates of Potential Output. Available at: https://bank.gov.ua/doccatalog/document?id=48800101

7. Altunbas, Y., Manganelli, S., and Marques-Ibanez, D., (2011). Bank Risk during the Financial Crisis - Do Business Models Matter?, Working Paper Series, No. 1394, Frankfurt am Main, Germany: European Central Bank.

8. Kohonen, T. (2001). Self-Organizing Maps. Berlin Heidelberg: Springer-Verlag.

9. Kohonen, T (2013). Essentials of the self-organizing map. Neural Networks, 37, 52-65.

10. Severin. E. (2010). Self organizing maps in corporate finance: Quantitative and qualitative analysis of debt and leasing, Neurocomputing, 73 (10-12), 2061-2067.

11. AghaeiRad, A., Chen, N. and Ribeiro, B. (2017). Improve credit scoring using transfer of learned knowledge from self-organizing map, Neural Computing \& Applications, 28 (6), 1329-1342.

12. Tkac, M. and Verner, R. (2015). Artificial neural networks in business: Two decades of research, Applied Soft Computing, 38, 788-804.

13. Sarlin, P and Peltonen, T. (2013). Mapping the state of financial stability» Journal Of International Financial Markets Institutions \& Money, 26, 46-76.

14. Severin, E (2012). Forecasting financial failure using a Kohonen map: A comparative study to improve model stability over time» European Journal Of Operational Research, 221 (2), 378-396.

15. Rutherford, M.W. (2016). Proposing a Financial Legitimacy Threshold in Emerging Ventures: A MultiMethod Investigation. Group \& Organization Management, 41, (6), 751-785.

16. Koc, Elcin K et al. (2014). Efficient adaptive regression spline algorithms based on mapping approach with a case study on finance. Journal Of Global Optimization, 60(1), 103-120.

17. Jarvinen, J., Linnakangas, J (2012) Firm Capabilities in the Finnish Forest Cluster: Comparisons Based on Self-Organizing Map. Silva Fennica, 46(1), 131-150.

18. Lin, W.Y., Hu, Y.H. and Tsai, C.F. (2012). «Machine Learning in Financial Crisis Prediction: A Survey». Ieee Transactions On Systems Man And Cybernetics Part C-Applications And Reviews, 42(4), 421-436.

19. Hsu, C.M. (2012). A hybrid procedure for stock price prediction by integrating self-organizing map and genetic programming, Expert Systems With Applications, 38(11), 14026-14036

20. Ayadi R.W et al. (2015). Banking business model monitor 2015: Europe. Centre for European Policy Studies and International Observatory on Financial Services Cooperatives. Available at: https://www.ceps.eu/system/files/Banking-Business-Models-Monitor-Europe-2015.pdf

21. Mergaerts, F and Vennet R. (2015). Business models and bank performance. A long-term perspective. 4th EBA Policy Research Workshop. Nov. 18. Available at: https://www.eba.europa. eu/documents/ 10180/1018121/Mergaerts\%2C\%20Vander+Vennet++Business+models+and+bank+performance.+A+long+ term+perspective+-+Paper.pdf.

22. Beltratti, A. and Stulz, R.M., (2012). The credit crisis around the globe: Why did some banks perform better? Journal of Financial Economics, 105(1), 1-17.

23. Huang, X., Zhou H. and Zhu H. (2011). Systemic Risk Contributions, Federal Reserve Board Finance and Economics Discussion Series 2011-08.

24. Drehmann, M. and Tarashev, N. (2011). Systemic Importance: Some Simple Indicators, Bank for International Settlements Quarterly Review, Bank for International Settlements, March.

25. Brownlees, C.T. and Engle R.F. (2010). Volatility, Correlation and Tails for Systemic Risk Measurement. Available at SSRN: http://ssrn.com/abstract=1611229. 
26. Boot, A. and Thakor, A.V. (2010). The Accelerating Integration of Banks and Markets and its Implications for Regulation, in A. Berger, P. Molyneux and J. Wilson (eds.), The Oxford Handbook of Banking, 58-90.

27. Bekaert, G., Ehrmann, M., Fratzscher, M. and Mehl, A. (2011). Global Crises and Equity Market Contagion. Available at: http://ssrn.com/abstract=1856881.

28. Acharya, V., Cooley T., Richardson M. and Walter I. (2010). Manufacturing Tail Risk: A Perspective on the Financial Crisis of 2007-09, Foundations and Trends in Finance, 4, 247-325.

29. Berger, A. and Bouwman C. (2010). How Does Capital Affect Bank Performance During Financial Crises? Wharton Financial Institutions Center Working Paper, 11-22.

30. De Jonghe, O. (2010). Back to the Basics in Banking? A Micro-analysis of Banking System Stability, Journal of Financial Intermediation, 19(3), 387-417.

31. Maddaloni, A. and Peydró J.L. (2011). Bank Risk Taking, Securitization, Supervision, and Low Interest Rates: Evidence from Lending Standards, Review of Financial Studies, 24(6), 2121-2165.

32. Baele, L., De Jonghe, O., and Vander Vennet, R. (2007). Does the stock market value bank diversification? Journal of Banking and Finance, 31(7), 1999-2023.

33. Hasan, I., Lozano-Vivas, A. and Pastor, J.T. (2001). European bank performance beyond country borders: what really matters? European Finance Review, 5(2), 141-165.

34. Billio, M., Getmansky, M., Lo, A.W. and Pelizzon, L. (2012). Econometric measures of connectedness and systemic risk in the finance and insurance sectors, Journal of Financial Economics, 104(3), 535-559.

35. Brandt, M.W., Brav, A., Graham, J. and Kumar, A. (2010). The idiosyncratic volatility puzzle: time trend or speculative episodes? Review of Financial Studies, 23(2), 863-899.

36. Coughlan, J., Shale, E. and Dyson, R. (2010). Including the customer in efficiency analysis: evidence of a hybrid relational-transactional approach", International Journal of Bank Marketing, 28(2), 136-149.

37. Greenwood, R., Landier, A. and Thesmar, D. (2015). Vulnerable banks, Journal of Financial Economics, 115(3), 471-485.

38. Hays, F., de Lurgio, S. and Gilbert, A. (2009). Efficiency ratios and community bank performance, Journal of Finance and Accountancy, 1(1), 1-15.

39. Paleologo, G., Elisseeff, A. and Antonini, G. (2010). Subagging for credit scoring models", European Journal of Operational Research, 201(2), 490-499.

40. Petersen, M. (2009). Estimating standard errors in finance panel data sets: comparing approaches, Review of Financial Studies, 22(1), 435-480.

41. Pistol, G. (2010). The role and importance of the strategic planning in bank marketing”, Annals of Spiru Haret University. Economic Series, 1(2), 153-161.

42. Zheng, D., Zhang, Y. and Wen, L. (2012). The credibility models with time changeable effects, Journal of Jiangxi Normal University: Natural Science Edition, 36(1), 249-252.

43. Tomkus, M. (2014). Identifying Business Models of Banks: Analysis of Biggest Banks from Europe and United States of America. Aarhus University: Business and Social Science. Available at: http://pure.au.dk/ portal/files/69715984/be_apendixu.pdf

44. Köhler M. (2015). Which banks are more risky? Th e impact of business models on bank stability, Journal of Financial Stability, 16, 195-212.

45. Laeven L. (2013)/ Corporate governance: What's special about banks? Annual Review of Financial Economics, 5, 63-92

46. Roengpitya, R. (2014). Bank business models, Bank for International Settlements. Available at: http://www.imf.org/external/pubs/ft/sdn/2014/sdn1404.pdf 


\section{Appendix}

Table A. Distribution of banks as of 01.01.2017 as compared to 01.01.2012

\begin{tabular}{|c|c|c|c|c|c|c|c|c|c|c|c|c|}
\hline \multirow{2}{*}{$\begin{array}{l}\text { No. } \\
\text { near }\end{array}$} & \multirow{2}{*}{$\begin{array}{l}\text { Number } \\
\text { in the } \\
\text { group }\end{array}$} & \multirow[b]{2}{*}{ Name of bank } & \multirow{2}{*}{$\begin{array}{c}\text { Structural and functional group } \\
01.10 .2017\end{array}$} & \multirow[b]{2}{*}{01.01 .2012} & \multicolumn{8}{|c|}{ The value of individual structural indicators as of 10.01.2017 } \\
\hline & & & & & nom & ROA & RA & $\mathrm{VL}$ & SAV & SAF & SAC & SPM \\
\hline 1 & 1 & Avanhard & investment & since 2004 & 54 & 7.7 & 11.3 & 36.1 & 5.1 & 0.0 & 57.1 & 3.1 \\
\hline 2 & 2 & Alpari Bank & investment & since 2003 & 89 & -1.5 & 0.0 & 0.6 & 1.5 & 0.0 & 94.1 & 0.0 \\
\hline 3 & 3 & Ap Bank & investment & investment & 71 & -0.7 & 0.6 & 30.6 & 3.1 & 0.0 & 36.6 & 0.0 \\
\hline 4 & 4 & Altbank & investment & bank/liabilities & 73 & 1.9 & 0.5 & 15.9 & 8.6 & 0.0 & 47.8 & 0.0 \\
\hline 5 & 5 & Pryvatbank & investment & centre & 1 & -0.8 & 75.0 & 13.2 & 7.7 & 3.3 & 40.3 & 5.5 \\
\hline 6 & 6 & Oshchadbank & investment & retail & 2 & 0.3 & 26.5 & 39.8 & 5.2 & 1.8 & 34.7 & 4.2 \\
\hline 7 & 7 & Ukreksimbank & investment & investment & 3 & 1.2 & 30.5 & 59.6 & 4.2 & 0.4 & 27.6 & 3.0 \\
\hline 8 & 8 & Ukrhazbank & investment & retail & 4 & 0.5 & 13.8 & 46.5 & 5.2 & 6.2 & 32.4 & 2.8 \\
\hline 9 & 9 & Raiffaizen Bank Aval & investment & retail & 5 & 8.3 & 22.8 & 24.8 & 10.4 & 15.9 & 2.9 & 3.9 \\
\hline 10 & 10 & Pershyi Ukr.Mizhnarodnyi Bank & investment & centre & 6 & 2.3 & 17.4 & 46.5 & 5.8 & 11.8 & 20.4 & 2.5 \\
\hline 11 & 11 & Ukrsybbank & investment & retail & 7 & 2.7 & 15.7 & 42.0 & 11.5 & 14.1 & 5.8 & 0.0 \\
\hline 12 & 12 & Kredi Ahrikol Bank & investment & centre & 11 & 3.8 & 7.2 & 37.4 & 6.7 & 9.0 & 9.3 & 0.0 \\
\hline 13 & 13 & Otp Bank & investment & retail & 12 & 3.3 & 25.6 & 31.5 & 7.7 & 20.1 & 12.4 & 0.3 \\
\hline 14 & 14 & Kredobank & investment & centre & 19 & 3.2 & 6.6 & 38.2 & 5.0 & 24.2 & 20.7 & 7.2 \\
\hline 15 & 15 & Bank Ukraina & investment & bank/liabilities & 21 & 1.4 & 5.7 & 21.0 & 3.0 & 0.5 & 20.7 & 2.1 \\
\hline 16 & 16 & Kredyt Dnipro & investment & centre & 23 & -8.0 & 29.6 & 51.8 & 6.0 & 5.3 & 2.5 & 0.0 \\
\hline 17 & 17 & Vostok & investment & centre & 25 & 0.9 & 3.1 & 43.8 & 12.2 & 0.4 & 5.2 & 7.9 \\
\hline 18 & 18 & Praveks-Bank & investment & retail & 31 & -2.1 & 0.7 & 26.9 & 12.9 & 5.8 & 36.3 & 0.2 \\
\hline 19 & 19 & Marfin Bank & investment & bank/liabilities & 32 & 1.7 & 14.2 & 46.2 & 8.6 & 16.1 & 20.3 & 0.6 \\
\hline 20 & 20 & Doiche Bank Dbu & investment & investment & 37 & 1.8 & 0.0 & 18.9 & 4.6 & 0.0 & 53.6 & 0.0 \\
\hline 21 & 21 & Bta Bank & investment & bank/liabilities & 38 & -5.7 & 19.1 & 13.6 & 2.0 & 1.3 & 41.3 & 0.0 \\
\hline 22 & 22 & Klirynhovyi Dim & investment & cash & 40 & -22.5 & 26.3 & 23.8 & 5.7 & 0.8 & 20.7 & 0.0 \\
\hline 23 & 23 & Poltava - Bank & investment & deposits/private & 43 & 3.0 & 4.7 & 12.1 & 7.7 & 3.0 & 22.5 & 0.0 \\
\hline 24 & 24 & Krystalbank & investment & investment & 59 & 4.3 & 3.5 & 18.4 & 10.1 & 8.0 & 32.0 & 0.0 \\
\hline 25 & 25 & Sitibank & investment & investment & 15 & 5.1 & 0.3 & 26.5 & 6.5 & 0.3 & 34.9 & 0.6 \\
\hline 26 & 26 & Seb Bank & investment & bank/liabilities & 44 & 1.6 & 0.0 & 32.1 & 4.0 & 0.0 & 12.3 & 0.1 \\
\hline 27 & 27 & Rvs Bank & investment & small/captive & 80 & -8.9 & 2.8 & 8.5 & 11.3 & 0.0 & 10.2 & 3.6 \\
\hline 28 & 28 & Rozrakhunkovyi Tsentr & investment & працює з 2004 & 81 & 1.2 & 0.0 & 0.1 & 1.5 & 0.0 & 71.0 & 64.7 \\
\hline 29 & 29 & Motor-Bank & investment & cash & 50 & 0.3 & 2.1 & 51.1 & 6.8 & 0.3 & 23.4 & 0.0 \\
\hline 30 & 30 & Metabank & investment & deposits/private & 62 & 2.9 & 5.4 & 16.8 & 6.4 & 4.4 & 32.2 & 0.0 \\
\hline 31 & 1 & Misto Bank & centre & cash & 39 & -5.5 & 12.6 & 28.7 & 4.8 & 10.2 & 18.0 & 11.4 \\
\hline 32 & 2 & Alfa-Bank & centre & centre & 8 & 0.1 & 18.7 & 60.6 & 5.1 & 17.5 & 0.0 & 1.4 \\
\hline 33 & 3 & Industrialbank & centre & centre & 34 & -0.8 & 9.2 & 39.7 & 5.2 & 2.7 & 8.5 & 5.5 \\
\hline 34 & 4 & Lviv & centre & centre & 46 & 1.4 & 6.2 & 36.7 & 6.3 & 4.7 & 10.2 & 0.1 \\
\hline
\end{tabular}


Table A (cont.) Distribution of banks as of 01.01.2017 as compared to 01.01.2012

\begin{tabular}{|c|c|c|c|c|c|c|c|c|c|c|c|c|}
\hline \multirow{2}{*}{$\begin{array}{l}\text { No. } \\
\text { near }\end{array}$} & \multirow[t]{2}{*}{$\begin{array}{l}\text { Number in } \\
\text { the group }\end{array}$} & \multirow[b]{2}{*}{ Name of bank } & \multirow{2}{*}{$\begin{array}{c}\text { Structural and functional group } \\
01.10 .2017 \\
\end{array}$} & \multirow[b]{2}{*}{01.01 .2012} & \multicolumn{8}{|c|}{ The value of individual structural indicators as of 10.01.2017 } \\
\hline & & & & & nom & ROA & RA & $\mathrm{VL}$ & SAV & SAF & SAC & SPM \\
\hline 35 & 5 & Mehabank & centre & centre & 22 & 0.1 & 7.3 & 46.5 & 4.4 & 10.0 & 0.5 & 1.4 \\
\hline 36 & 6 & Bank Investytsii, Zaoshchadzhen & centre & centre & 28 & 0.3 & 6.9 & 68.2 & 4.9 & 0.4 & 3.4 & 0.0 \\
\hline 37 & 7 & Oksi Bank & centre & deposits/private & 70 & 0.1 & 2.3 & 41.3 & 6.7 & 4.5 & 10.0 & 0.0 \\
\hline 38 & 8 & Pivdennyi & centre & centre & 14 & 0.4 & 7.6 & 52.8 & 7.9 & 1.4 & 5.0 & 16.3 \\
\hline 39 & 9 & Taskombank & centre & centre & 20 & 0.5 & 5.9 & 42.3 & 3.6 & 5.9 & 9.3 & 1.7 \\
\hline 40 & 10 & Bank Sich & centre & centre & 58 & 0.1 & 1.8 & 43.1 & 9.7 & 0.3 & 11.3 & 7.4 \\
\hline 41 & 1 & Aktsent-Bank & retail & retail & 29 & 5.4 & 18.9 & 10.7 & 3.8 & 72.3 & 7.0 & 0.0 \\
\hline 42 & 2 & Ukrsotsbank & retail & retail & 10 & -6.5 & 84.5 & 37.9 & 6.8 & 33.9 & 6.4 & 0.7 \\
\hline 43 & 3 & Ideia Bank & retail & retail & 33 & 1.6 & 21.9 & 11.0 & 4.5 & 68.9 & 5.6 & 0.0 \\
\hline 44 & 4 & Forvard & retail & retail & 42 & -11.2 & 14.7 & 11.4 & 4.6 & 61.6 & 0.0 & 19.7 \\
\hline 45 & 1 & Kominvestbank & current accounts & bank/assets & 49 & 0.2 & 7.2 & 39.5 & 13.2 & 3.8 & 0.8 & 0.8 \\
\hline 46 & 2 & Ekspres-Bank & current accounts & cash & 47 & 0.1 & 12.1 & 27.1 & 15.8 & 6.3 & 19.1 & 20.7 \\
\hline 47 & 3 & Polikombank & current accounts & deposits/private & 68 & 0.1 & 5.2 & 20.5 & 8.8 & 0.7 & 3.7 & 0.0 \\
\hline 48 & 4 & Prokredyt Bank & current accounts & retail & 16 & 2.9 & 4.0 & 31.3 & 5.6 & 1.6 & 4.9 & 1.2 \\
\hline 49 & 5 & Pershyi Investytsiinyi Bank & current accounts & deposits/private & 48 & 0.0 & 4.3 & 26.0 & 9.2 & 0.6 & 20.9 & 0.0 \\
\hline 50 & 6 & Hrant & current accounts & deposits/private & 51 & 5.3 & 3.5 & 28.8 & 5.0 & 2.7 & 5.6 & 0.0 \\
\hline 51 & 7 & Radabank & current accounts & deposits/private & 56 & 1.6 & 11.6 & 17.8 & 7.6 & 3.0 & 9.4 & 0.0 \\
\hline 52 & 8 & Aiboks & current accounts & deposits/private & 64 & 0.0 & 3.0 & 14.5 & 12.2 & 11.3 & 7.8 & 0.2 \\
\hline 53 & 9 & Akordbank & current accounts & centre & 69 & 4.3 & 3.2 & 26.4 & 24.5 & 1.5 & 12.9 & 0.0 \\
\hline 54 & 1 & Vernum & deposits/private & small/captive & 77 & 1.4 & 6.3 & 19.1 & 4.6 & 2.7 & 9.9 & 0.0 \\
\hline 55 & 2 & Hlobus & deposits/private & small/captive & 36 & 1.8 & 7.9 & 20.9 & 5.9 & 15.4 & 0.0 & 7.1 \\
\hline 56 & 3 & Arkada & deposits/private & deposits/private & 41 & 0.6 & 4.2 & 0.2 & 5.6 & 23.9 & 2.5 & 0.0 \\
\hline 57 & 4 & Zemelnyi Kapital & deposits/private & deposits/private & 76 & 0.5 & 0.1 & 18.7 & 3.8 & 0.2 & 7.7 & 0.0 \\
\hline 58 & 5 & Ukrainskyi Kapital & deposits/private & small/captive & 63 & 1.3 & 5.1 & 23.7 & 6.0 & 2.1 & 1.0 & 5.0 \\
\hline 59 & 6 & Asvio Bank & deposits/private & deposits/private & 55 & 4.0 & 8.8 & 10.8 & 6.5 & 0.5 & 17.4 & 0.0 \\
\hline 60 & 7 & Yevroprombank & deposits/private & deposits/private & 66 & 2.8 & 40.1 & 44.3 & 2.8 & 0.5 & 0.0 & 0.0 \\
\hline 61 & 8 & Skai Bank & deposits/private & deposits/private & 78 & 0.7 & 8.3 & 4.5 & 4.1 & 2.0 & 4.0 & 0.0 \\
\hline 62 & 9 & Bank 3/4 & deposits/private & small/captive & 60 & 3.6 & 3.3 & 26.9 & 7.0 & 25.1 & 7.2 & 0.0 \\
\hline 63 & 10 & Trast-Kapital & deposits/private & bank/assets & 84 & -1.2 & 22.8 & 7.4 & 5.6 & 4.0 & 7.4 & 0.0 \\
\hline 64 & 1 & Sberbank & bank/liabilities & bank/liabilities & 9 & 0.3 & 47.3 & 80.8 & 5.0 & 2.5 & 4.3 & 67.7 \\
\hline 65 & 2 & Vtb Bank & bank/liabilities & bank/liabilities & 17 & -14.2 & 138.2 & 52.9 & 2.2 & 1.4 & 0.0 & 59.5 \\
\hline 66 & 3 & Prominvestbank & bank/liabilities & bank/liabilities & 13 & -29.2 & 131.9 & 72.5 & 3.3 & 0.2 & 0.1 & 5.4 \\
\hline 67 & 4 & Universal Bank & bank/liabilities & retail & 26 & 2.9 & 20.8 & 56.2 & 5.4 & 42.3 & 4.6 & 0.0 \\
\hline 68 & 5 & Pireus Bank & bank/liabilities & bank/liabilities & 35 & 1.0 & 21.8 & 54.3 & 6.6 & 14.3 & 13.1 & 29.7 \\
\hline
\end{tabular}


Table A (cont.). Distribution of banks as of 01.01.2017 as compared to 01.01.2012

\begin{tabular}{|c|c|c|c|c|c|c|c|c|c|c|c|c|}
\hline \multirow{2}{*}{$\begin{array}{l}\text { No. } \\
\text { near }\end{array}$} & \multirow{2}{*}{$\begin{array}{l}\text { Number in } \\
\text { the group }\end{array}$} & \multirow[b]{2}{*}{ Name of bank } & \multirow{2}{*}{$\begin{array}{l}\text { Structural and functional group } \\
01.10 .2017\end{array}$} & \multirow[b]{2}{*}{01.01 .2012} & \multicolumn{8}{|c|}{ The value of individual structural indicators as of 10.01 .2017} \\
\hline & & & & & nom & ROA & RA & $\mathrm{VL}$ & SAV & SAF & SAC & SPM \\
\hline 69 & 6 & Bm Bank & bank/liabilities & centre & 53 & -14.8 & 179.7 & 58.0 & 8.2 & 11.1 & 0.0 & 0.4 \\
\hline 70 & 7 & Vies Bank & bank/liabilities & bank/liabilities & 30 & 4.0 & 29.4 & 59.3 & 6.5 & 13.8 & 13.5 & 60.7 \\
\hline 71 & 1 & Kredyt Optyma Bank & small/captive & small/captive & 87 & 0.0 & 11.1 & 1.2 & 4.8 & 23.4 & 0.0 & 0.0 \\
\hline 72 & 2 & Familnyi & small/captive & small/captive & 83 & 1.5 & 17.2 & 25.4 & 8.2 & 5.2 & 56.0 & 6.6 \\
\hline 73 & 3 & Alians & small/captive & small/captive & 74 & 1.1 & 10.6 & 24.9 & 18.2 & 0.7 & 0.0 & 0.0 \\
\hline 74 & 4 & Ukrainskyi Bank Rekonstr.Ta Rozv. & small/captive & small/captive & 86 & -3.7 & 0.0 & 52.4 & 4.2 & 0.0 & 19.3 & 0.0 \\
\hline 75 & 5 & Apeks-Bank & small/captive & bank/assets & 88 & 63.0 & 72.7 & 3.8 & 4.5 & 11.0 & 0.0 & 0.0 \\
\hline 76 & 6 & Kredyt Yevropa Bank & small/captive & bank/liabilities & 45 & 1.1 & 17.4 & 78.7 & 2.0 & 1.9 & 3.2 & 75.1 \\
\hline 77 & 1 & Konkord & cash & deposits/private & 72 & 0.1 & 4.5 & 14.0 & 7.3 & 2.2 & 13.5 & 0.0 \\
\hline 78 & 2 & Promyslovo-Finansovyi Bank & cash & cash & 79 & 3.9 & 6.4 & 13.4 & 15.3 & 2.7 & 16.7 & 0.0 \\
\hline 79 & 3 & Ukrbudinvestbank & cash & cash & 65 & 0.3 & 4.1 & 23.0 & 15.8 & 1.6 & 20.5 & 5.9 \\
\hline 80 & 4 & Komertsiinyi Industrialnyi Bank & cash & cash & 67 & 0.5 & 1.9 & 28.0 & 9.7 & 2.5 & 27.5 & 0.0 \\
\hline 81 & 5 & Mizhnarodnyi Investytsiinyi Bank & cash & cash & 24 & 1.5 & 5.9 & 58.1 & 6.3 & 0.3 & 21.3 & 1.8 \\
\hline 82 & 6 & Kredytvest Bank & cash & bank/assets & 52 & 3.2 & 0.3 & 45.1 & 3.0 & 0.1 & 2.9 & 16.6 \\
\hline 83 & 7 & Yuneks Bank & cash & deposits/private & 61 & 14.6 & 18.8 & 18.0 & 8.7 & 3.5 & 20.6 & 0.0 \\
\hline 84 & 8 & Divi Bank & cash & bank/assets & 85 & 0.3 & 3.4 & 20.0 & 7.3 & 15.9 & 4.0 & 0.0 \\
\hline 85 & 9 & Tsentr & cash & cash & 82 & 1.8 & 5.3 & 8.9 & 6.1 & 0.2 & 10.0 & 0.0 \\
\hline 86 & 10 & Portal & cash & 2004 & 90 & 3.7 & 6.6 & 5.8 & 2.8 & 9.1 & 0.6 & 0.0 \\
\hline 87 & 1 & Finansova Initsiatyva & problem banks & centre & 18 & -8.5 & 99.1 & 6.9 & 0.4 & 0.0 & 0.0 & 60.7 \\
\hline 88 & 2 & Rodovid Bank & problem banks & problem banks & 27 & -95.7 & 164.4 & 1.3 & 1.3 & 0.0 & 0.0 & 94.0 \\
\hline 89 & 3 & Bohuslav & problem banks & deposits/private & 57 & 0.9 & 4.3 & 6.0 & 5.2 & 0.7 & 25.8 & 13.4 \\
\hline 90 & 4 & Finansovyi Partner & problem banks & 2003 & 91 & 3.2 & 9.8 & 23.0 & 0.6 & 0.1 & 43.2 & 0.0 \\
\hline 91 & 5 & Yunison & problem banks & 2003 & 75 & -9.8 & 34.9 & 36.2 & 8.3 & 4.7 & 0.0 & 0.0 \\
\hline
\end{tabular}

